\title{
Heavy Load Rollers in Logistic Systems
}

\author{
B. Künne, V. Mehlan, A. Langenohl
}

\begin{abstract}
Wheels with polyurethane bandages are in common use in logistic systems with friction gear actuation. Many research projects have studied the mechanical construction of these heavy load wheels. The studies have been theoretical as well as experimental. Research interests at the department of machine elements include the wear in the presence of intermediate material on the contact area between the bandage surface and the contact surface on which the wheel rolls off. This problem, which is observed when examining this tribochemical system, has not been studied before. Within this project both one-phase intermediate materials such as sand, water, cutting-cooling-emulsion, metal splinters and two-phase intermediate materials such as sand/water and combinations of the latter were taken into consideration. In addition, the exposure of the bandage hardness, the cross linking agent of the polyurethane, the mechanical stress, and the slip are observed. The analysis of the experimental results indicates that friction gear actuators can be constructed abrasion-optimised, taking into account special interfering effects in the form of intermediate materials in the contact area.
\end{abstract}

Keywords: wear, polyurethane, heavy load wheel, heavy load rollers, abrasive, tribochemical, hydrolysis, abrasion, intermediate material.

\section{Introduction}

Rollers and wheels made of thermoplastics or elastomeric plastics are common in various technical areas. They have displaced rollers made of grey cast iron, steel, and light metal, especially in the field of light and middle load conveyors. The advantages of polymeric materials for use as rollers are shown below:

- low deadweight,

- quiet running at higher material attenuation,

- economically efficient manufacturing,

- electrical and thermal insulation,

- high breaking strain,

- beneficial load transmission features,

- self lubrication features, or no need for lubrication,

- protection of the lane,

- durability against corrosive effects,

- physiological safeness.

In particular the good load transmission features, the quiet running and the attenuation features, especially of polyurethane, have led to the use of this material for powered wheels. In this paper, tests are shown concerning wear performance and its optimisation for use in transmission during friction actuations for the handling of piece goods. A method is described which experimentally observes the basics for abrasion-optimised construction of powered polyurethane coated wheels, taking into special consideration the influence of intermediate materials.

\section{Basics of heavy load rollers}

In principle, a powered wheel consists of a polyurethane bandage on a hub made of material with a higher strength than the bandage. This bandage is cast around the hub by a low pressure system. A hub made of metal is used for wheels which are needed for higher loads. Thermoplastics like polyamide are more widely used for basic applications than materials like steel, cast iron and aluminium.

Since friction and the resulting wear, which is dependent on the presence and the type of abrasive intermediate material, has to be handled when using polymers in mechanical loaded systems, it is desirable to analyse the wear performance under the influence of these intermediate materials.

There is a basic difference between the use of plastics as a sliding friction partner of a tribological system and the use of plastics as a roller material in transmission during friction actuations. On the one hand, the sliding friction coefficient should be minimised in order to minimise losses in power resulting from the wear, and on the other hand the abrasion coefficient should be high in order to realise a high positive connection. Indeed, both cases exert minimisation of abrasion.

\section{State of the art}

In the so-called visco-elastic roller contact problem, a usually cylindrical body with visco-elastic behaviour rolls off on a normally even surface with high stiffness. This problem has been extensively examined for the tensions and strains occurring in the bandage, both in theory and in practice. Indeed, the abrasion is extensively unconsidered in this research. When considering abrasion, it is common practise to draw conclusions from the wear due to the sliding action, as defined in several standards. The results of these considerations are projected to the individual case. The disadvantages of this method are the natural inaccuracy as well as the complete neglect of the influence of slip, which results from the tangential load transmission, and the effect of an inferring intermediate material.

An example of an individual case is the air-filled wheel of a motorcar, which shows substantial differences from the use of polymeric bandages in handling systems. Due to these differences, the projection of the test results on to this case is impossible or deficient.

\section{Experimental setup and execution}

In experiments the abrasion performance of heavy load wheels was studied especially under influence of intermediate materials. The Fig. 1 shows the process parameters which were chosen.

In addition to the visible changes of the wheel bandage without magnification, the damage was microscopically analysed. The abrasion was determined by measuring the 


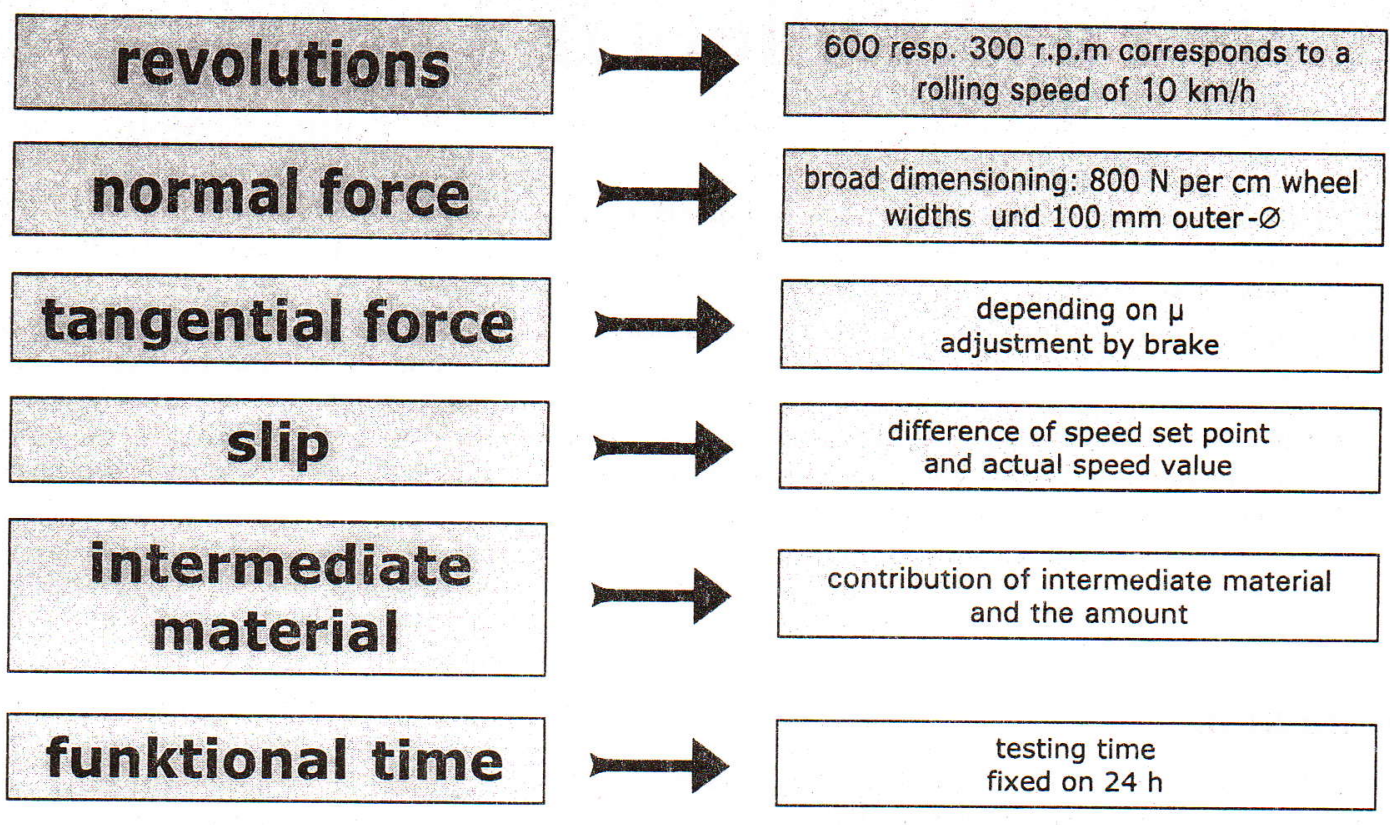

Fig. 1: Measured variables for determining of the load

decrease in diameter and weight. In order to carry out the tests, the following boundary conditions were necessary:

- Only heavy load wheels with polymeric bandages and metal hubs are examined.

- The hardness grade of the bandages is between 70 and 92 Shore-A.

- The opposite face is metallic.

- The opposite face is a cylindric surface with a diameter of $600 \mathrm{~mm}$.

- The following intermediate materials are inserted into the contact area to study their effect on the abrasion performance:

1. solids:

$\square$ quarry sand,

$\square$ metal splinters.

2. liquids:

$\square$ water,

$\square$ oil-water emulsion.

3. mixture:

$\square$ quarry sand and water,

$\square$ metal splinters and oil-water emulsion.

The dimensions of the sample wheels:

\begin{tabular}{|c|c|c|}
\hline Diameter & Width & Bandage thickness \\
\hline $100 \mathrm{~mm}$ & $30 \mathrm{~mm}$ & $10 \mathrm{~mm}$ \\
\hline $200 \mathrm{~mm}$ & $50 \mathrm{~mm}$ & $15 \mathrm{~mm}$ \\
\hline
\end{tabular}

The transfused torques, the normal force, and the unwind velocity are adjusted to a maximum value dependent on the intermediate material for each wheel. Due to space and costs, heavy load wheels are always used at their mechanical load limit.

\section{Results of research}

Using heavy load wheels, abrasion occurs basically independently of the individual case and also independently of the boundary conditions. This means that a heavy load wheel is subject to fatigue. Fig. 2 shows the abrasion in its absolute weight and dependencies on the intermediate material and bandage hardness.

The intermediate material affects the slip performance and also the abrasion of a powered friction wheel. In addition to the chemical and physical interaction between the intermediate material and the surfaces of the examined roller and counter wheel, a basic influence of the intermediate material is the separation of the two surfaces of the wheels from each other. So the power transmission between the surfaces changes. Especially the allocation of the transfused force to the friction force components (adhesion, cohesion, hysteresis, and viscosity) follows a different pattern. The abrasion under the influence of water is obviously higher than in the other tests. This is especially interesting because of the fact that no effect is expected with water as the intermediate material. An explanation for the high wear based upon chemical processes lies in the effects of hydrolysis. Under hydrolysis, saponification of the ester groups occurs. If the ester bond bridges are broken up, new alcohol and carboxyl groups are formed. Due to the creation of these groups, the hydrolysis becomes advanced. So its impact is self-preserving and self-energising.

The values of the abrasion under the influence of abrasive particles such as quarry sand and metal splinters lay below those of the tests with water. However, these tests brought a distinctive abrasion, which can be concluded from the creation of stress cracks in the surface and following a break out of material particles.

The different abrasion performance over the bandage width is shown in Fig. 3. In addition, the impact of the stress distribution on the abrasion performance is pointed out. 


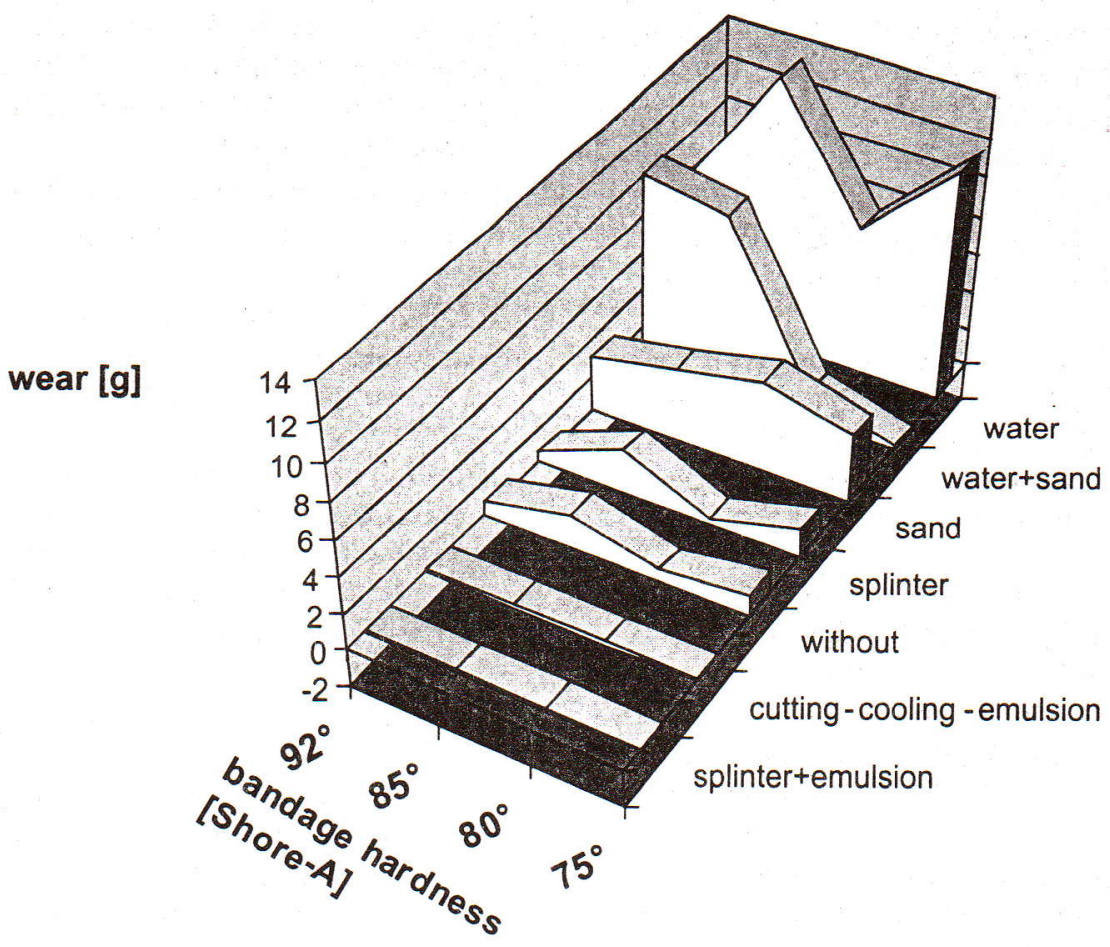

Fig. 2: Influence of intermediate material and bandage hardness
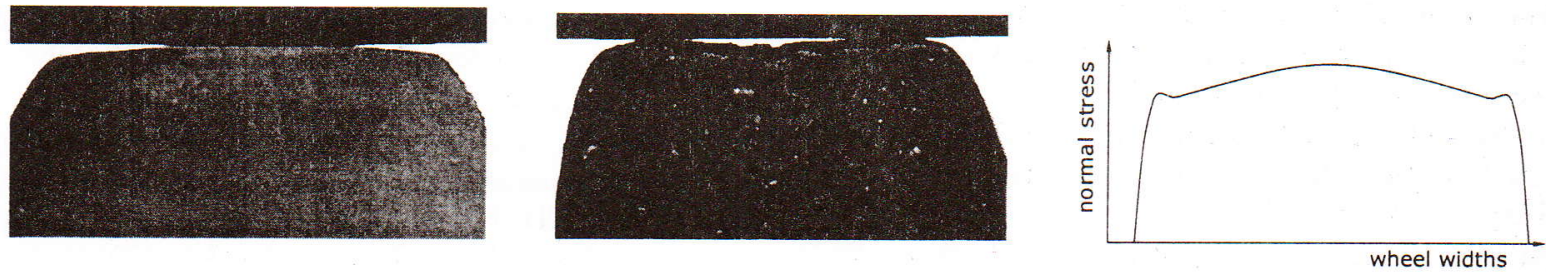

Fig. 3: Surface after impact of water (left) and sand (middle); normal stress distribution in the contact area

The abrasion mechanisms are structured in two types: abrasive wear and chemical corrosion reactions. These abrasion types can also occur in combination, but under special circumstances the interacting effects absorb each other. This is shown by the results of the experiments in which water and sand were used as a two-phase intermediate material. When examining the abrasion in greater detail, we can see that the tangential stress in the bandage surface is crucial to the expected level of wear, because the crack propagation is greatly affected by the stress distribution in the surface. In the chemical corrosion of the bandage, on the other hand, the slip plays a decisive role. Since the slip is significantly affected by the process of the normal stress, it is expected that the maximum abrasion, due to chemical corrosion, occurs at the edges. The reason for this is the occurrence of a lower normal force under an equal elastic deformation, so that the surface at that particular location starts to slip earlier.

\section{Conclusion}

For the first time the wear of a wheel body under close-to-reality loading cases has been examined. It is now possible to design friction gear drives taking into account to cer- tain failure influences in the form of different intermediate materials under the consideration of maximum power transmission. Since the wear of the wheel bandages showed the highest values under the impact of water, further research in this direction and the examination of potential coherences is recommended.

\section{References}

[1] Böhm, F., Knothe, K.: Hochfrequenter Rollkontakt der Fahrzeugräder. Ergebnisse aus dem gleichnamigen Sonderforschungsbereich an der TU Berlin; Deutsche Forschungsgemeinschaft, Wiley-VCH, 1998.

[2] Bufler, H.: Beanspruchung und Schlupf beim Rollen elastischer Walzen. Forschung auf dem Gebiet des Ingenieurwesens 27, No. 4, 1961, p. 121-126.

[3] DIN 50320: Verschleiß; Begriffe; Systemanalyse von Verschleißvorgängen; Gliederung des Verschleißgebietes. Deutsche Norm, Berlin: Beuth Verlag, Köln 12.1979.

[4] DIN 50321: Verschleiß-Messgrößen. Deutsche Norm, Berlin: Beuth Verlag, Köln 12.1979. 
[5] DIN 50324: Prüfung von Reibung und Verschleiß. Deutsche Norm, Berlin: Beuth Verlag, Köln 07.1992.

[6] DIN 53516: Prüfung von Kautschuk und Elastomeren, Bestimmung des Abriebs. Deutsche Norm, Berlin: Beuth Verlag, Köln 06.1987.

[7] Erhard, G.: Zum Reibungs- und Verschleißverhalten von Polymerwerkstoffen. Dissertationsschrift TH Karlsruhe, 1980.

[8] Grosch, K. A.: The Relation between the Friction and Visco-elastic Properties of Rubber. Proceedings of the Royal Society of London, Bd A 274, 1963, p. 21-39.

[9] Hertz, H.: Über die Berührung fester elastischer Körper. J. Reine und Angewandte Mathematik 92, 1882, p. 156-171.

[10] Heuel, A., Kellermann, H. G., Weiß, H.: Theoretische Betrachtungen zum Reibungs- und Verschleißverhalten von Elastomeren auf glatten Oberflächen. Universität-Gesamthochschule Siegen, Institut für Werkstofftechnik, 1997.

[11] Hiss, F., Knothe, K., Wang, G.: Stationärer Rollkontakt für Walzen mit viskoelastischen Bandagen. Konstruktion 44, 1992, p. 105-112.

[12] Knothe, K., Wang, G.: Zur Theorie der Rollreibung zylindrischer Kunststofflaufräder. Konstruktion 41, 1989, p. 193-200.

[13] Kragelski, I. V., Dobycin, M. N., Kombalov, V. S.: Grundlagen der Berechnung von Reibung und Verschleiß. Carl Hanser Verlag, 1983.

[14] Künne, B.: Einführung in die Maschinenelemente, Gestaltung, Berechnung, Konstruktion. 2. überarbeitete Auflage, Teubner Verlag, Stuttgart 2001.

[15] Lütkebohle, H.: Roll- und Wälzreibung zylindrischer Räder aus thermoplastischen Kunststoffen. Dissertationsschrift TU, Berlin 1984.

[16] Möhler, P.: Lokale Kraftgrößen in der Berührungsfläche zwischen Kunststoffrad und Stahlfahrbahn. Forschung im Ingenieurwesen, Bd. 61, 1995, p. 29-41.

[17] Polzer, G., Meißner, F.: Grundlagen zu Reibung und Verschleiß. 2. Auflage, VEB Deutscher Verlag für Grundstoffindustrie, Leipzig 1982.

[18] Qiao, L.: Beanspruchung und Wärmeentwicklung in rollenden Rädern aus viskoelastischen Werkstoffen. VDI-Fortschrittberichte Reihe 1: Konstruktionstechnik/Maschinenelemente, No. 289, VDI-Verlag 1997.

[19] Rehbein, P., Wallascheck, J.: Friction and Wear Behaviour of Polymer/Steel and Alumina/Alumina under High-frequency Fretting Conditions. Wear Band 216 Ausgabe 2, April 1998, p. 97-105.

[20] Sackmann, F. W.: Die Lebensdauer von Wälzrädern mit weichelastischem Belag bei Übertragung von Tangentialkraft. Dissertationsschrift TU Braunschweig 1980.
[21] Severin, D.: Betriebsfestigkeitsuntersuchungen an thermoplastischen Kunststoffrollen bis $125 \mathrm{~mm}$ Durchmesser. Institut für Fördertechnik und Getriebetechnik TU Berlin, Forschungsbericht 1989.

[22] Severin, D., Hammele, W.: Zur Kraftübertragung zwischen Kunststoffrad und Stahllaufbahn, Teil 1 und 2. Konstruktion 41, 1989, Teil 1, p. 123-129, Teil 2, p. 163-171.

[23] Severin, D., Kühlken, B.: Tragfähigkeit von Kunststoffräderm unter Berücksichtigung der Eigenerwärmung, Teil 1 und 2. Konstruktion 43, 1991, Teil 1, p. 65-71, Teil 2, p. 153-160.

[24] Severin, D., Liu, X.: Zum Rad-Schiene-System in der Fördertechnik - Berechnung und beanspruchungsgerechter Einsatz von Kunststoffrädern. Dhf 5/99, p. 40-46.

[25] Severin, D., Lütkebohle, H.: Rollreibung zylindrischer Laufräder aus Kunststoff. Konstruktion 37, 1985, p. 177-184.

[26] Severin, D., Lütkebohle, H.: Wälzreibung zylindrischer Räder aus Kunsistoff. Konstruktion 38, 1986, p. 173-179.

[27] Severin, D., Qiao, L., Hammele, W.: A Finite Element Solution for the Three-dimensional Contact Problem of Polymer-covered Rollers. FEM Today and the Future, edited by John Robinson, Seventh World Congress on Finite Element Methods, Monte Carlo 1993, p. 223-229.

[28] Severin, D., Qiao, L.: The Thermomechanical Calculation of Polymer Roller with Finite Element Method. Edinburgh: Civil-Comp Press, 1996, p. 73-77.

[29] Wang, G., Knothe, K.: Stress Analysis for Rolling Contact between two Viscoelastic Cylinders. Transactions of the ASME, Vol. 60, Juni 1993.

[30] Wang, G., Knothe, K.: Theorie und numerische Behandlungdes allgemeinen rollenden Kontaktes zweier viskoelastischer Walzen. VDI-Fortschrittberichte Reihe 1: Konstruktionstechnik/Maschinenelemente, Nr. 165; VDI-Verlag1988.

[31] Yin, X.: Experimentelle Untersuchung des instationären Rollkontaktes zwischen Rad und Fahrbahn. VDI-Fortschrittberichte Reihe 12: Verkehrstechnik/Fahrzeugtechnik, No. 313, VDI-Verlag 1997.

Prof. Dr.-Ing. Bernd Künne

e-mail: b.kuenne@me.mb.uni-dortmund.de

Dr.-Ing. Volker Mehlan

Aljoscha Langenohl

Universität Dortmund

Fachgebiet Maschinenelemente

Leonhard-Euler-Strasse 5

44227 Dortmund, Germany 